\title{
Neuroprotective Effect of Isobenzofuranones on Hydrogen Peroxide-Mediated Redox Imbalance in Primary Cultures of Hippocampal Neurons
}

lára Mariana Léllis Ribeiro'

https://orcid.org/0000-0003-4711-8172

Wagner Luiz Pereira ${ }^{3}$

https://orcid.org/0000-0001-9515-3832

Leonardo Brandão Nogueira ${ }^{2}$

https://orcid.org/0000-0001-5108-2315
Laser Antônio Machado Oliveira1
https://orcid.org/0000-0002-9918-932X

Róbson Ricardo Teixeira ${ }^{3}$

https://orcid.org/0000-0003-3181-1108

Katiane de Oliveira Pinto Coelho Nogueira ${ }^{1 *}$ https://orcid.org/0000-0001-5495-2558

${ }^{1}$ Federal University of Ouro Preto, Department of Biological Sciences, Ouro Preto, Minas Gerais, Brazil; ${ }^{2}$ Federal University of Ouro Preto, Department of Geology, Ouro Preto, Minas Gerais, Brazil; ${ }^{3}$ Federal University of Viçosa, Department of Chemistry, Viçosa, Minas Gerais, Brazil.

Received: 2019.02.07; Accepted: 2019.11.26.

${ }^{*}$ Correspondence: katiane@ufop.edu.br; Tel.: +55-31-35591215

\section{HIGHLIGHTS}

- Primary neuronal cultures as a model on studies of cytotoxicity.

- Isobenzofuranones described neuroprotective activity.

- Isobenzofuranones control reactive oxygen species in cultured neurons.

Abstract: In live organisms, there is a balance between the production of reactive oxygen species (ROS) and their neutralization. The increased level of these species leads to a condition called redox imbalance. The aim of this study was to evaluate the protective action of isobenzofuranones in primary cultures of hippocampal neurons subjected to redox imbalance. To accomplish this, MTT and LIVE/DEAD assays were initially performed. In the cultures pretreated with isobenzofuranones 1 and 2, there was a higher number of live cells when compared to that in the untreated ones. Regarding redox imbalance, there was a significant increase in the intracellular levels of ROS. The cultures pretreated with isobenzofuranones showed a reduction in ROS levels. Lipid peroxidation caused by oxidative damage was significantly reduced in the cultures pretreated with isobenzofuranones 1 and 2. Taken together, these data show the ability of isobenzofuranones 1 and 2 to significantly minimize cytotoxicity, cell death, intracellular levels of ROS and lipid peroxidation induced by redox imbalance. These results suggest that isobenzofuranones 1 and 2 represent a possible alternative therapy for the neurodegenerative disturbances that are triggered by ROS production increases.

Keywords: reactive oxygen species, isobenzofuranones, phthalide, hippocampal neurons, redox imbalance. 
Under physiological conditions, there is a balance between the levels of reactive oxygen species (ROS) and their neutralization by antioxidant systems. When this balance is lost, there is an increase in ROS in the organism. The increased level of these species leads to a condition called redox imbalance [1], which can result in irreversible oxidative damage to proteins, lipids and DNA [2-5]. In the literature, there is evidence that redox imbalance is linked to the pathogenesis of several neurodegenerative diseases, such as Alzheimer's and Parkinson's diseases [6,7], ischaemic brain damage [8], and amyotrophic lateral sclerosis [9]. The human body has its own natural antioxidant defence system to protect it from the harmful effects of ROS [10]. Synthetic antioxidant compounds act by strengthening and/or helping the natural defence system of the body [11-13]. Isobenzofuranones, also known as phthalides, are chemical compounds with a structure involving a benzene ring fused to a $y$-lactone ring [14]. These substances have attracted the attention of several researchers due, in part, to the range of their biological effects, including antioxidant activity [15]. In China, an isobenzofuranone derivative, 1-3-n-butylphthalide (NBP), was originally extracted as a pure component of Apium graveolens Linn seeds and has been synthesized and developed as a neuroprotective agent for cerebral ischaemia [16,17]. In addition, studies on 3-butyl-6-bromo-1 $(3 \mathrm{H})$-isobenzofuranone (Br-NBP) have demonstrated a reduction in the volume of cerebral infarction and the amelioration of neurological behavioural deficits in rats with transient middle cerebral artery occlusion [18]. These compounds can be of synthetic or natural origins, which makes them part of a growing group of substances with therapeutic properties that have been used in the search for new medicines [19-21]. Based on the importance of the effects of antioxidant on redox imbalance and considering the importance of this process in the progression of neurodegenerative diseases, the present study aimed to evaluate the protective action of isobenzofuranones in primary cultures of hippocampal neurons exposed to redox imbalance. Within this context, the compounds 3-(2-hydroxy-4,4dimethyl-6-oxocyclohex-1-enyl) isobenzofuran-1(3H)-one (isobenzofuranone 1) and 2-(-oxo-1,3-dihydroisobenzofuran-1-il) $1 \mathrm{H}$-indene-1,3(2H)-dione (isobenzofuranone 2) (scheme 1) were evaluated. Previous in silico analyses have revealed that these isobenzofuranones exhibit physicochemical and pharmaceutical properties, which allows their in vitro activity to be evaluated [22]. To evaluate isobenzofuranones $\mathbf{1}$ and $\mathbf{2}$, primary cultures of hippocampal neurons were used, as these cells are more susceptible to redox imbalance and are robustly involved in memory and learning processes, which are directly affected by neurodegenerative diseases [23,24].

\section{MATERIAL AND METHODS}

\section{SYNTHESIS OF COMPOUNDS 1 AND 2}

Isobenzofuranones 1 and $\mathbf{2}$ (Figure 1) were synthesized as previously described [22]. Briefly, condensation reactions, which were promoted by DBU, between phthalaldehydic acid and the appropriate diketones produced isobenzofuranones $\mathbf{1}$ and $\mathbf{2}$. These isobenzofuranones were purified by silica-gel column chromatography and fully characterized by spectroscopy (IR and NMR) and mass spectrometry.

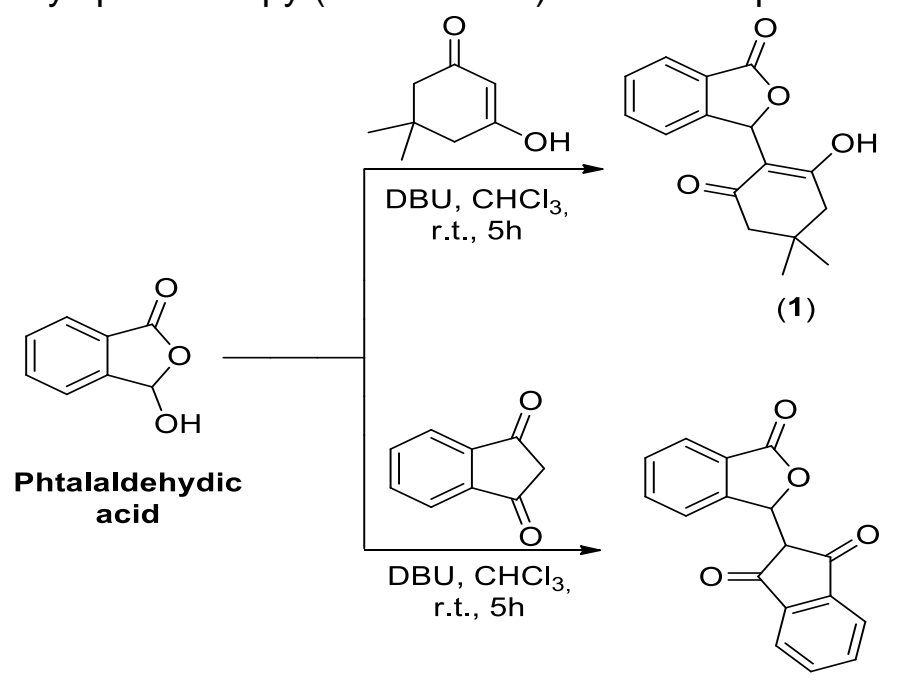

(2)

Figure 1. Synthesis of isobenzofuranones 1 and 2. 
Male and female C57BL/6 mice were kept in the Animal Science Center of the Federal University of Ouro Preto. All procedures performed on the animals were approved by the Animal Ethics Committee (protocol 45/2015). Primary cultures of hippocampal neurons were obtained from mouse embryos as described previously $[25,26]$. Briefly, brains were dissected from embryonic day 17 (E17) embryos. We considered embryos to be at E1 when the dam was found to be sperm-positive. The hippocampi were separated from the embryonic brains and placed in cold Hanks' balanced salt solution (Thermo Scientific) in a sterile microtube. The hippocampi were first incubated with trypsin $\left(0.25 \%\right.$; Sigma-Aldrich) for 20 minutes at $37^{\circ} \mathrm{C}$. After that, the trypsin was neutralized with plating medium (Eagle's minimum essential medium (Thermo Scientific) containing $10 \%$ FBS (Invitrogen) and antibiotics (100 mg/mL streptomycin and 100 units $/ \mathrm{mL}$ penicillin). Afterwards, the hippocampi were dissociated mechanically in plating medium. The cells were then plated at a density of $10^{5}$ or $10^{6}$ per well on dishes pre-coated with $10 \mathrm{mg} / \mathrm{mL}$ poly-L-lysine (Sigma) and kept at $37^{\circ} \mathrm{C}$ and $5 \% \mathrm{CO}_{2}$. The plating medium was replaced by maintenance medium (neurobasal medium, B-27, L-glutamine (Thermo Scientific), $100 \mathrm{mg} / \mathrm{mL}$ streptomycin and 100 units $/ \mathrm{mL}$ penicillin) $4 \mathrm{~h}$ after the cells were plated. The experiments were carried out 6 to 10 days after the neurons were seeded onto the dishes at an appropriate density according to each experimental scale.

\section{Treatment of the primary hippocampal neurons}

For each evaluated compound (isobenzofuranones 1 and 2, Figure 1), a $2 \mathrm{mM}$ stock solution in DMSO (20\%) was prepared. The stock solutions were diluted to obtain concentrations of 50,100 and $150 \mu \mathrm{M}$. To control for the cytotoxicity of DMSO, its final concentration was kept at $0.05 \%$ for all treatments. The neurons were seeded onto 96-well dishes coated with poly-L-lysine $\left(1.0 \times 10^{5} \mathrm{cells} /\right.$ well $)$. After 8 days, the cells were treated with 50,100 and $150 \mu \mathrm{M}$ of isobenzofuranone and incubated for $2 \mathrm{~h}$ in a humidified chamber at $37^{\circ} \mathrm{C}$ with $5 \% \mathrm{CO}_{2}$. After the treatment with isobenzofuranones 1 and 2 , redox imbalance was induced for $3 \mathrm{~h}$ with hydrogen peroxide $(100 \mu \mathrm{M})[27,28]$.

\section{Evaluation of cytotoxicity}

The metabolic activity of hippocampal neurons was evaluated by the MTT (3-(4,5-dimethylthiazol-2-yl)2,5-diphenyltetrazolium bromide, Sigma Aldrich) assay (adapted from Sozio and coauthors [11]). Cell viability was based on the ability of viable cells to reduce MTT to the coloured formazan salt. The neurons were incubated for $2 \mathrm{~h}$ with isobenzofuranones 1 and 2 at concentrations of 50,100 and $150 \mu \mathrm{M}$ in 96 -well dishes coated with poly-L-lysine $\left(1.0 \times 10^{5} \mathrm{cells} /\right.$ well). After that, redox imbalance was induced with $100 \mu \mathrm{M}$ of hydrogen peroxide $\left(\mathrm{H}_{2} \mathrm{O}_{2}\right)$ for $3 \mathrm{~h}$. Then, the medium was replaced with $0.5 \mathrm{mg} / \mathrm{mL} \mathrm{MTT}$, and the dish was incubated for $4 \mathrm{~h}$ at $37^{\circ} \mathrm{C}$. After this time, the dish was incubated with $10 \%$ SDS solution for $16 \mathrm{~h}$ at $37^{\circ} \mathrm{C}$ to solubilize the formazan salt. Finally, the absorbance was measured at $570 \mathrm{~nm}$ with a VICTOR microplate reader (Multidetector VICTOR ${ }^{\text {TM }}$ X3, Perkin Elmer).

\section{Cell viability}

For cell viability, the LIVE/DEAD (Thermo Scientific) assay was used (adapted from Beraldo and coauthors [29]). The LIVE/DEAD assay is a cell viability assay that uses two spectra of fluorescence and simultaneously identifies live and dead cells with calcein-AM and ethidium-1 (EthD-1) homodimers. Calcein-AM can permeate the cell membrane; however, after being cleaved by esterase, which is present in the cytoplasm of live cells, it is no longer capable of passing through the membrane and it remains stuck in the cell, where it produces an intense and uniform green fluorescence. Fluorescence was observed at 495 and $635 \mathrm{~nm}$. Mouse primary hippocampal neurons were seeded onto poly-L-lysine-coated 4-well dishes at a density of $1.0 \times 10^{6}$ cells/well and cultured for 10 days. On day 11, the neurons were treated for $2 \mathrm{~h}$ with isobenzofuranones 1 and 2 and then incubated with $\mathrm{H}_{2} \mathrm{O}_{2}(100 \mu \mathrm{M})$ for $3 \mathrm{~h}$. Afterwards, $20 \mu \mathrm{L}$ of the solution prepared from the LIVE/DEAD kit was added to each well for 45 minutes. Live and dead cells were counted based on fluorescence images taken with a Zeiss LSM780 confocal microscope using a 20X/0.5 objective and a wavelength of $488 \mathrm{~nm}$. The cell death rate was calculated as the percentage of dead cells relative to the total amount of cells.

\section{ROS intracellular measurement}

Intracellular ROS production was assessed by a fluorescence assay that employed 2,7-dichlorofluorescein diacetate (H2DCFDA). The methodology was adapted from a work previously reported by Halliwell and Whiteman30. H2DCFDA readily diffuses into cells, and intracellular esterases promote the cleavage of 
the acetate groups to produce H2DCF, which remains inside the cells. Intracellular ROS oxidize H2DCF to form the highly fluorescent 2,7-dichlorofluorescein (2,7-DCF). After treatment with isobenzofuranones 1 and 2 and the induction of redox imbalance, the medium was replaced by an H2DCFDA $(2 \mu \mathrm{M})$ solution for 45 minutes. After that, the wells were washed three times with colourless calcium $\left(\mathrm{Ca}^{2+}\right)$ and magnesium $\left(\mathrm{Mg}^{2+}\right)$ free Hanks' balanced salt solution. Fluorescence was monitored every 30 minutes for $3 \mathrm{~h}$ after the addition of $100 \mu \mathrm{M} \mathrm{H}_{2} \mathrm{O}_{2}$ using a VICTOR (multidetector VICTOR ${ }^{\mathrm{TM}}$ X3, PerkinEImer) microplate reader at wavelengths of 495 and $530 \mathrm{~nm}$.

\section{Lipid peroxidation}

To analyse the membrane damage caused by redox imbalance induction, we adapted the protocol reported by Angelova and collaborators ${ }^{31}$. Mouse primary hippocampal neurons were seeded onto poly-Llysine-coated 96-well dishes at a density of $1.0 \times 10^{5}$ cells/well and cultured for 6 days. On day 7 , the cells were treated with isobenzofuranones 1 and 2 for $2 \mathrm{~h}$. After this time, the medium was replaced by a solution containing BODIPY ${ }_{581 / 591} \mathrm{C} 11(2 \mu \mathrm{M})$ and incubated for 30 minutes. Then, the wells were washed three times with colourless $\mathrm{Ca}^{2+}$ and $\mathrm{Mg}^{2+}$ free Hanks' balanced salt solution. Before reading the results, redox imbalance was induced by the addition of $100 \mu \mathrm{M} \mathrm{H}_{2} \mathrm{O}_{2}$. Readings were performed every 30 minutes for $3 \mathrm{~h}$, with the first reading at time 0 ', using a VICTOR (multidetector VICTOR ${ }^{\text {TM }} \mathrm{X} 3$, PerkinElmer) microplate reader at wavelengths of 495 and $530 \mathrm{~nm}$.

\section{STATISTICAL ANALYSIS}

The results were analyzed by analysis of variance (ANOVA) followed by Tukey's test. The differences were considered significant when the $p$-values were $\leq 0.01$. The numeric values are presented as the average \pm standard error of the mean (SEM).

\section{RESULTS AND DISCUSSION}

\section{Cytotoxicity and cell viability}

The cytotoxicity of isobenzofuranones 1 and 2 was evaluated by analyses of hippocampal neuron metabolism in response to isobenzofuranones and the induction of redox imbalance separately and in combination. As shown in Figure 1, there was a significant reduction in the metabolism of the untreated cultures compared to the cultures pretreated with isobenzofuranones 1 and 2 (Figure 1).

A

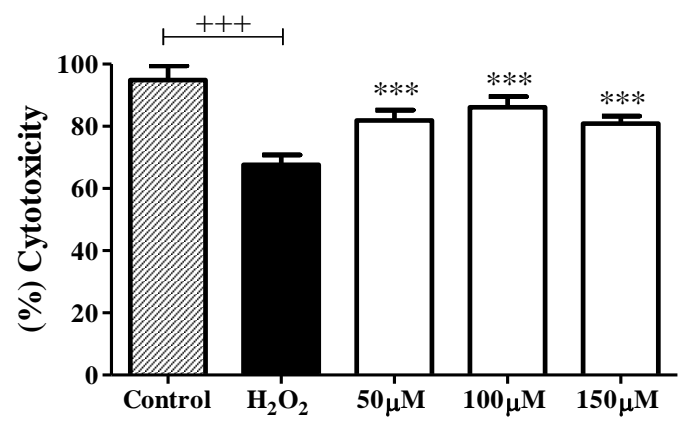

B

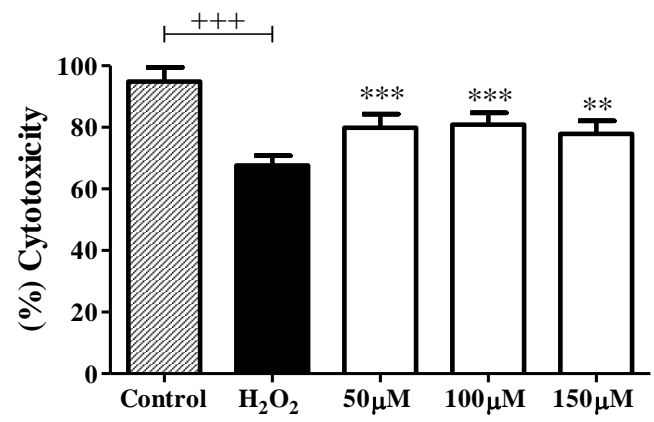

Figure 1. Cells were pretreated with isobenzofuranones $1(A)$ and $2(B)$ at concentrations of $50 \mu \mathrm{M}, 100 \mu \mathrm{M}$ and 150 $\mu \mathrm{M}$ for $2 \mathrm{~h}$. Next, $100 \mu \mathrm{M} \mathrm{H}_{2} \mathrm{O}_{2}$ was, added for $3 \mathrm{~h}$. The data represent the mean \pm SEM. (+++) $\mathrm{p}<0.001$ between the control group and the $\mathrm{H}_{2} \mathrm{O}_{2}$-untreated group. $\left.{ }^{(* *}\right) \mathrm{p}<0.001$ and $\left.{ }^{* \star}\right) \mathrm{p}<0.01$ between the $\mathrm{H}_{2} \mathrm{O}_{2}$-untreated group and the $\mathrm{H}_{2} \mathrm{O}_{2}$-treated groups.

To confirm the neuroprotective effect of isobenzofuranones 1 and 2 on the cell death induced by $\mathrm{H}_{2} \mathrm{O}_{2}$, the LIVE/DEAD assay was carried out. In the cultures pretreated with isobenzofuranones $\mathbf{1}$ and $\mathbf{2}$, there were a greater number of live cells compared to that in the untreated cultures (Figure 2 and SM1). 

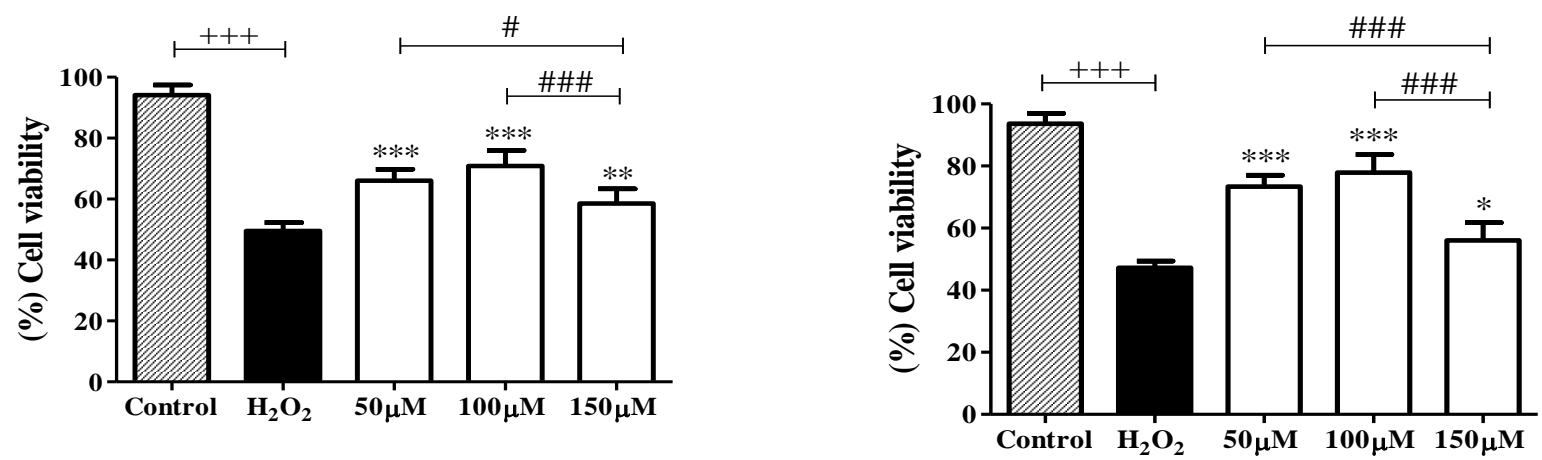

Figure 2. Cells were pretreated with isobenzofuranones 1 (A) and 2 (B) at concentrations of $50 \mu \mathrm{M}, 100 \mu \mathrm{M}$ and 150 $\mu \mathrm{M}$ for $2 \mathrm{~h}$. Next, $100 \mu \mathrm{M} \mathrm{H}_{2} \mathrm{O}_{2}$ was added for $3 \mathrm{~h}$. The graphics represent the percentage of live cells from the captured images. The data represent the mean \pm SEM. $(+++) \mathrm{p}<0.001$ compared to the control group and the $\mathrm{H}_{2} \mathrm{O}_{2}$-untreated group. $\left(^{* * *}\right) \mathrm{p}<0.001,\left(^{* *}\right) \mathrm{p}<0.01$ and $\left(^{*}\right) \mathrm{p}<0.05$ between the $\mathrm{H}_{2} \mathrm{O}_{2}$-untreated group and the $\mathrm{H}_{2} \mathrm{O}_{2}$-treated group. $(\# \# \#) p<0.001$ (\#) $p<0.05$ between the groups treated with different concentrations.

Although isobenzofuranones attenuated the decrease in cell metabolism and, consequently, the neuronal death induced by redox imbalance, previous studies have demonstrated the cytotoxic effects of isobenzofuranones in the U937 (lymphoma) and K562 (myeloid leukaemia) cell lines[22] as well as in the HL-60 leukaemia, SF295 glioblastoma and MDA-MB435 melanoma cancer cell lines [32]. In the present investigation, it was shown that isobenzofuranones $\mathbf{1}$ and $\mathbf{2}$ were not toxic to cells at low concentrations. This can be explained by the hormesis effect, which describes a biphasic effect of isobenzofuranones characterized by a beneficial effect at lower concentrations and a cytotoxic effect at higher doses.

\section{ROS Intracellular Measurement}

Hydrogen peroxide is an endogenous source of hydroxyl free radicals that contributes to the background level of cellular oxidative stress [33]. After the induction of redox imbalance with $\mathrm{H}_{2} \mathrm{O}_{2}$, there was a significant increase in intracellular ROS levels during the $3 \mathrm{~h}$ of analysis. (Figure 3 and SM 2). However, in the primary cell cultures pretreated with isobenzofuranones, a significant reduction in ROS levels was observed (Figure 3 and SM 2). These results corroborate the findings of Xu and Zao [34], who reported that PC12 cells treated with the compound 3-butyl-6-fluoro-1(3H)-isobenzofuranone and subjected to redox imbalance showed a reduction in ROS levels. Strobel and coauthors [35] observed that isobenzofuranones extracted from the fungus Pestalotiopsis microspora were able to reduce the hydroxyl radical $(\mathrm{OH} \cdot)$ levels that were chemically induced by hydrogen peroxide in the samples tested. Thus, considering that, in the present investigation, redox imbalance was induced by $\mathrm{H}_{2} \mathrm{O}_{2}$, it is plausible that the neuroprotective effect of isobenzofuranones 1 and 2 is related to their ability to scavenge free radical species.

A

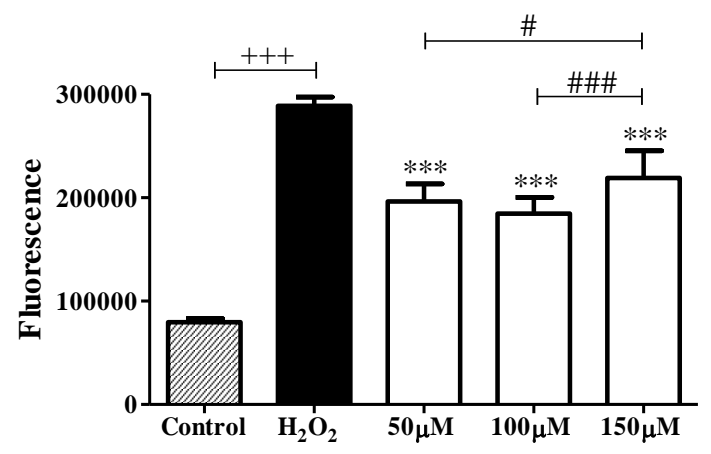

B

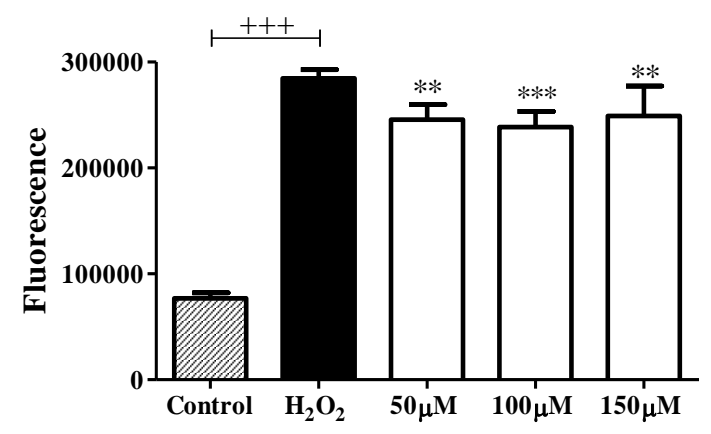

Figure 3. Cells were pretreated with isobenzofuranones 1 (A) and 2 (B) at concentrations of $50 \mu \mathrm{M}, 100 \mu \mathrm{M}$ and 150 $\mu \mathrm{M}$ for $2 \mathrm{~h}$. Next, $100 \mu \mathrm{M}$ of $\mathrm{H}_{2} \mathrm{O}_{2}$ was added for $3 \mathrm{~h}$. Immediately afterwards, the fluorescence of 2,7-dichlorofluorescein $\left(\mathrm{H}_{2}\right.$ DCFDA) was measured. The data represent the mean \pm SEM. $(+++) \mathrm{p}<0.001$ between the control group and the $\mathrm{H}_{2} \mathrm{O}_{2}$-untreated group. $\left.{ }^{* * *}\right) \mathrm{p}<0.001$ and $\left.{ }^{* *}\right) \mathrm{p}<0.01$ between the $\mathrm{H}_{2} \mathrm{O}_{2}$-untreated group and the $\mathrm{H}_{2} \mathrm{O}_{2}$-treated group. $(\# \#) p<0.001$ and (\#) $p<0.05$ between the groups treated with different concentrations. 
Lipid peroxidation caused by oxidative damage was significantly reduced in the cultures pretreated with isobenzofuranones 1 and 2 at $50 \mu \mathrm{M}, 100 \mu \mathrm{M}$ and $150 \mu \mathrm{M}$ (Figure 4). It was also possible to observe a significant difference between the groups treated with compound 2 at concentrations of $100 \mu \mathrm{M}$ and $150 \mu \mathrm{M}$ (Figure 4B). The same did not occur with the groups treated with compound 1 (Figure 4A).

A

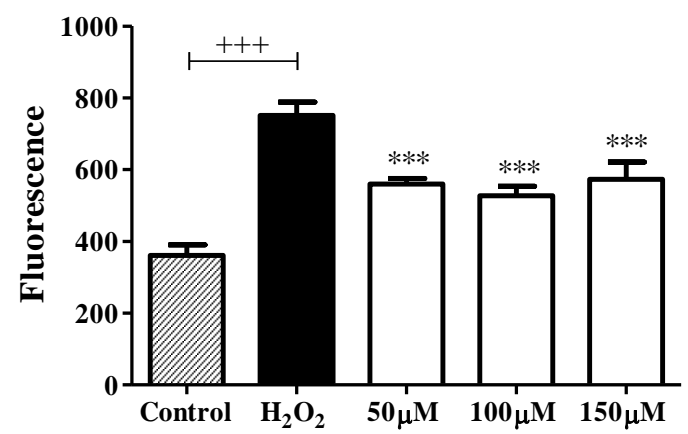

B

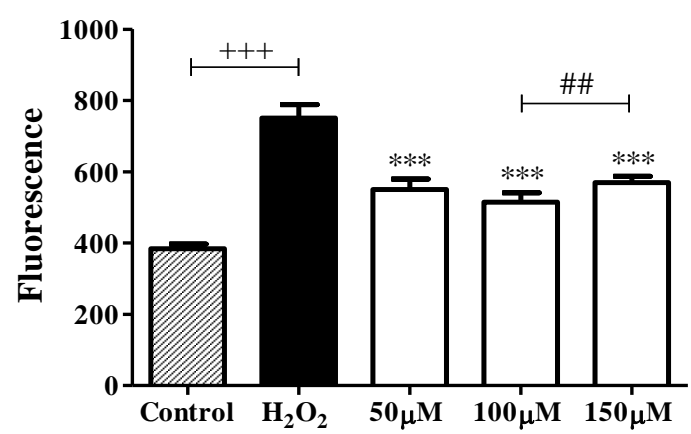

Figure 4. Cells were pretreated with isobenzofuranones $1(A)$ and $2(B)$ at concentrations of $50 \mu \mathrm{M}, 100 \mu \mathrm{M}$ and 150 $\mu \mathrm{M}$ for $2 \mathrm{~h}$. Next, $100 \mu \mathrm{M} \mathrm{H}_{2} \mathrm{O}_{2}$ was added for $3 \mathrm{~h}$. Then, the spectral emission levels of BODIPY $581 / 591 \mathrm{C}_{11}$ were quantified. The data represent the mean \pm SEM. $(+++) p<0.001$ between the control group and the group $\mathrm{H}_{2} \mathrm{O}_{2}$-untreated group. $\left({ }^{* * *}\right) p<0.001$ between the $\mathrm{H}_{2} \mathrm{O}_{2}$-untreated group and the $\mathrm{H}_{2} \mathrm{O}_{2}$-treated groups. (\#\#) $p<0.01$ between the groups treated with different concentrations.

Similar results to those achieved when PC12 cells were treated with 3-butyl-6-fluoro- $1(3 \mathrm{H})$-isobenzofuranone and 3-butyl-6-bromo-1 $(3 \mathrm{H})$-isobenzofuranone $[30,34]$ were observed. Taken together, these data suggest that, because their concentrations can be increased without causing cytotoxicity, compounds 1 and 2 are able to decrease lipid peroxidation caused by ROS and act in a more efficient way to protect against membrane damage during redox imbalance in primary cultures of neurons.

\section{CONCLUSION}

The present study showed the ability of isobenzofuranones $\mathbf{1}$ and $\mathbf{2}$ to significantly decrease cytotoxicity, cell death, intracellular ROS levels and lipid peroxidation induced by redox imbalance. The findings reported herein are significant since this is the first study to show the protective activity of isobenzofuranones on redox imbalance induced in primary cultures of mouse hippocampal neurons. In addition, the performance of these compounds under physiological conditions was described to improve our understanding. Taken together, the data suggest that isobenzofuranones 1 and 2 represent possible alternative therapies for neurodegenerative disturbances that are triggered by ROS production increases, but further study is required to confirm this assumption.

Funding: This research was funded by the Minas Gerais Funding Foundation - Fapemig, grant number APQ-0084814.

Acknowledgements: The authors acknowledge the support of the Biotechnology Post-Graduation Program, the Biology Science Research Nucleus (NUPEB) and the Federal University of Ouro Preto.

Conflicts of Interest: The authors declare no conflict of interest.

\section{REFERENCES}

1. Farrugia G, Balzan R. Oxidative stress and programmed cell death in yeast. Front Oncol. 2012 Jun;2:64. doi:10.3389/fonc.2012.00064.

2. Cui H, Kong $\mathrm{Y}$, Zhang H. Oxidative stress, mitochondrial dysfunction, and aging. J Signal Transduct. 2012 Oct;2012:1-13. doi:10.1155/2012/646354.

3. Hayes JD, Flanagan JU, Jowsey, IR. Glutathione transferases. Annu Rev Pharmacol Toxicol. 2005 Sep;45:51-88. doi:10.1146/annurev.pharmtox.45.120403.095857.

4. Lam YT. Critical roles of reactive oxygen species in age-related impairment in ischemia-induced neovascularization by regulating stem and progenitor cell function. Oxid Med Cell Longev. 2015 Nov;2015:7095901. doi:10.1155/2016/7095901.

5. Yan MH, Wang X, Zhu X. Mitochondrial defects and oxidative stress in Alzheimer disease and Parkinson disease. Free Radic Biol Med. 2013 Sep;62:90-101. 
6. Bozzali M, Dowling C, Serra L, Spano B, Torso M, Marra C et al. The impact of cognitive reserve on brain funtional connectivity in Alzheimer's disease. J Alzheimers Dis. 2015 Jan;44(1):243-50.

7. Wood-Kaczmar A, Gandhi S, Wood NW. Understanding the molecular causes of Parkinson's disease. Trends Mol Med. 2006 Nov;12(11):521-8.

8. Doyle K, Simon R, Stenzel-Poore M. Mechanisms of ischemic brain damage. Neuropharmacology. 2008 Sep;55:310-8.

9. Federico A, Cardaioli E, Pozzo P, Formichi P, Gallus GN, Radi E. Mitochondria, oxidative stress and neurodegeneration. J Neurol Sci. 2012 Nov;322(1-2):254-62. doi:10.1016/j.jns.2012.05.030.

10. Siti HN, Kamisah Y, Kamsiah J. The role of oxidative stress, antioxidants and vascular inflammation in cardiovascular disease (a review). Vascul Pharmacol. 2015 Aug;71:40-56. doi:10.1016/j.vph.2015.03.005.

11. Sozio P, Cerasa LS, Laserra S, Cacciatore I, Cornacchia C, Di Fillipo ES et al. Memantine-sulfur containing antioxidant conjugates as potential prodrugs to improve the treatment of Alzheimer's disease. Eur J Pharm Sci. 2013;49:187-198.

12. Boaventura BCB, Silva EL, HaiLiu R, Prudêncio ES, Pietro PFD, Becker AM, Amboni RDMC. Effect of yerba mate (Ilex paraguariensis A. St. Hil.) infusion obtained by freeze concentration technology on antioxidant status of healthy individuals. LWT - Food Sci Technol. 2015 Jul;62(2):948-954.

13. Turkez $\mathrm{H}$, Togar B, Di Stefano A, Taspinar N, Sozio P. Protective effects of cyclosativene on $\mathrm{H}_{2} \mathrm{O}_{2}$-induced injury in rat primary cerebral cortex cells. Cytotechnology. 2015 Mar;67(2):299-309. doi:10.1007/s10616-013-9685-9.

14. Zhang M, Wang A, He W, He P, Xu B, Xia T et al. Effects of fluoride on the expression of NCAM, oxidative stress, and apoptosis in primary cultured hippocampal neurons. Toxicology. $2007 \mathrm{Jul} ; 236: 208-216$.

15. Melo JOF, Donnici CL, Augusti R, Ferreira VF, Souza MCBV, Ferreira MLG et al. Heterociclos 1,2,3-triazólicos: Histórico, métodos de preparação, aplicações e atividades farmacológicas (1,2,3-Triazole Heterocycles: History, preparation methods, applications and pharmacological activities). Quim Nova. 2006 Jun;29(3):569-579. doi:10.1590/S0100-40422006000300028.

16. Peng $\mathrm{Y}$, Xing $\mathrm{CH}$, Lemere $\mathrm{CA}$, Chen GQ, Wang L, Feng YP, Wang XL. I-3-n-Butylphthalide ameliorates betaamyloid-induced neuronal toxicity in cultured neuronal cells. Neurosci Lett. 2008;434:224-229.

17. Peng Y, Zeng XK, Feng YP, Wang XL. Antiplatelet and antithrombotic activity of L-3-n-utylphthalide in rats. J Cardiovasc Pharmacol. 2004 Jun;43:876-881.

18. Ma F, Gao Y, Qiao H, Hu X, Chang J. Antiplatelet activity of 3-butyl-6-bromo-1(3H)-isobenzofuranone. J Thromb Thrombolysis. 2012 Jan;33(1):64-73. doi:10.1007/s11239-011-0647-9.

19. Jain V, Baitharu I, Barhwal K, Prasad D, Singh SB, Ilavazhagan G. Enriched environment prevents hypobaric hypoxia induced neurodegeneration and is independent of antioxidant signaling. Cell Mol Neurobiol. 2012;32:599611.

20. Newman DJ, Cragg GM. Natural products as sources of new drugs from 1981-2014. J Nat Prod. 2016 Mar;79(3):629-61. doi:10.1021/acs.jnatprod.5b01055.

21. Ntie-Kang F, Telukunta KK, Doring K, Simoben CV, Moumbock AF, Malange YI, et al. NANPDB: A resource for natural products from Northern African sources. J Nat Prod. 2017;80:2067-2076.

22. Teixeira RR, Bressan GC, Pereira WL, Ferreira JG, de Oliveira FM, Thomaz DC. Synthesis and antiproliferative activity of C-3 functionalized isobenzofuran-1(3H)-ones. Molecules. 2013;18:1881-96.

23. Roy DS, Arons A, Mitchell TI, Pignatelli M, Ryan TJ, Tonegawa S. Memory retrieval by activating engram cells in mouse models of early Alzheimer's disease. Nature. 2016 Mar;531(7595):508-12. doi:10.1038/nature17172.

24. Shrestha P, Klann E. Alzheimer's disease: Lost memories found. Nature. 2016; 531:450-451.

25. Seibenhener ML, Wooten MW. Isolation and culture of hippocampal neurons from prenatal mice. J Vis Exp. 2012 Jul;(65). pii: 3634. doi:10.3791/3634.

26. Kaech S, Banker G. Culturing hippocampal neurons. Nature protocols. 2006 Jan;1(5):2406-15.

27. Whittemore ER, Loo DT, Watt JA, Cotman CWA. A detailed analysis of hydrogen peroxide-induced cell death in primary neuronal culture. Neuroscience. 1995 Aug;67(4):921-32.

28. Xiang J, Wan C, Guo R, Guo D. Is hydrogen peroxide a suitable apoptosis inducer for all cell types? BioMed Res Int. 2016 Jul;2016:1-6. Doi:10.1155/2016/7343965.

29. Beraldo FH, Ostapchenko VG, Caetano FA, Guimaraes ALS, Ferretti GDS, Daude N, et al. Regulation of amyloid $\beta$ oligomer binding to neurons and neurotoxicity by the prion protein-mGluR5 complex. J Biol Chem. 2016 Aug;291:21945-21955.

30. Halliwell B, Whiteman M. Measuring reactive species and oxidative damage in vivo and in cell culture: how should you do it and what do the results mean? Br J Pharmacol. 2004 May;142(2):231-55.

31. Angelova PRS, Horrockset MH, Klenerman D, Gandhi S, Abramov, AY, Shchepinov MS. Lipid peroxidation is essential for $\alpha$-synuclein-induced cell death. J Neurochem. 2015 May;133(4):582-9. doi:10.1111/jnc.13024. 
32. Logrado PL, Santos CO, Romeiro LA, Costa AM, Ferreira JR, Cavalcanti BC et al. Synthesis and cytotoxicity screening of substituted isobenzofuranones designed from anacardic acids. Eur J Med Chem. 2010;45:3480-3489.

33. Pohanka M. Alzheimer's disease and oxidative stress: a review. Curr Med Chem. 2014;21(3):356-64. doi:10.2174/09298673113206660258.

34. Xu L, Ji MX, Zao N, Ji BS. 3-butyl-6-fluoro-1 (3H)-isobenzofuranone, a derivative of dl-n-butylphthalide, attenuates hydrogen peroxide-induced damage in PC12 cells. Drug Develop Res. 2011;72:259-264.

35. Strobel G, Ford E, Worapong J, Harper JK, Arif AM, Grant DM, et al. Isopestacin, an isobenzofuranone from Pestalotiopsis microspora, possessing antifungal and antioxidant activities. Phytochemistry. 2002; 60(2):179-183.

(c) 2020 by the authors. Submitted for possible open access publication under the terms and conditions of the Creative Commons Attribution (CC BY NC) license (https://creativecommons.org/licenses/by-nc/4.0/). 